\title{
A gazdaságtudomány magyarországi helyzete és kapcsolódási pontjai a gazdasági fejlesztésekkel
}

\section{The Status of Economics in Hungary and Its Interfaces with Business Developments}

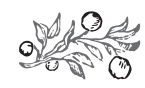

Összefoglalás

A tanulmány kiemeli az oktatási, oktatási, képzési reformok szerepét, figyelmet fordítva a globalizált világgazdaság és gazdálkodásszervezés kihívásait ellensúlyozó gazdaságtudományi újszerúségek tudományterületi kapcsolatrendszerére, amely hazánkban újszerú szemléletet és gondolkodást jelent. A gazdaságtudományi szakok jelentôs igényt elégítenek ki, nemcsak a vállalati szférát megcélozva, hanem intézményi szinten is a legnépszerúbbek közé tartoznak a magyar felsôoktatásban. A magyar oktatási politika törekvése a gazdaságtudományi szakok nemzetközi erôsítése és elfogadottságának széles körú növelése. A magyar oktatás széles kapcsolatban áll a kkv- és a nagyvállalati szektorral, segítve a K+F+I-tevékenységek megvalósulását.

Journal of Economic Literature (JEL) kódok: O3, H75, I23, I25

Kulcsszavak: gazdaságtudomány, kutatás-fejlesztés, innováció, kkv-szektor, felsôoktatás, Magyarország

Dr. ZÉman Zoltán, egyetemi tanár, intézetigazgató, Szent István Egyetem

Üzleti Tudományok Intézete (zeman.zoltan@gtk.szie.hu). 
Polgári Szemle $\cdot$ 15. évfolyam 1-3. szám

\section{Summary}

The paper highlights the role of educational and training reforms, touching upon the interrelationships between the novelties in economics, which offset the challenges posed by the globalised world economy and economy management, considered to be a novel approach and thinking in Hungary. The various specialisations in economics satisfy significant demand and in addition to targeting the corporate sector they are also among the most popular ones in Hungarian higher education. Hungarian education policy-makers endeavour to extensively improve the international reputation and acceptance of the various fields in economics. Hungarian education has extensive relationships with the SME and large corporate sectors, as it facilitated the implementation of R\&D\&I activities.

Journal of Economic Literature (JEL) codes: O3, H75, I23, I25

Keywords: economics, research and development, innovation, SME sector, higher education, Hungary

\section{BEVEZETÉS}

A tanulmányban elsôsorban az oktatás aktuális kérdésének bemutatására kerül sor, valamint a területen végbemenô egyes átalakulási folyamatok áttekintésére vállalkozunk. Az európai és magyar közegben a kutatás-fejlesztés kapcsán kialakuló viták alaphangját egyfelól az EU újra napirendre túzött lisszaboni stratégiája adja, mely az oktatást, a kutatást és az innovációt magában foglaló „tudásháromszöget” az európai versenyképesség egyik alappilléreként határozza meg. Az „európai álomnak” a tudástársadalom fogalma köré épül retorikáját ugyanakkor beárnyékolják a statisztikai adatok, amelyek a kontinens pozícióinak gyengülésérôl szólnak egy fokozódó globális versenyben.

A K+F-szektor szerkezetében és múködésében fellépó átalakulásokról nem minden esetben képesek számot adni a társadalomtudományok hagyományos elméletei és eszközei. Habár a közgazdaságtan meghatározó iskolája továbbra is a neoklasszikus irányzat, a közgazdasági alapokra épüló innovációmenedzsment jelentôs figyelmet szentel az evolúciós gazdaságtani elméleteknek is. Az utóbbiak ugyanis alkalmasabbnak tûnnek arra, hogy figyelembe vegyék az „új gazdaság” társadalmi beágyazottságát és ebből adódóan nemlineáris dinamikáját. A kutatás-fejlesztés olyan típusú átalakulásaira hívjuk fel a figyelmet, amelyek új indikátorok kidolgozását kívánják meg. Az előre nem tervezett, paradigmaváltást képviselő újítások hatásának elemzéséhez, illetve a meglévô technológiák újszerú felhasználására épülő „társadalmi” innovációk és az esztétikai jellegú fejlesztésekben (brand, dizájn) megjelenô kulturális tartalmak értékeléséhez új mérôszámok bevezetésére van szükség. A már ma is mérhetô változásokat diagnosztizáló tanulmányok vizsgálataihoz nem egyes technológiai szektorok, hanem különbözô geopolitikai környezetek adták a keretet. A kutatási és fejlesztési tevékenység globalizálódási folyamatát követhetjük figyelemmel, melynek nyertesei a nemzetközi K+F-piacon egyre nagyobb súllyal megjelenô Kína és India. 
Zéman Zoltán: A gazdaságtudomány magyarországi helyzete és kapcsolódási pontjai...

A Magyar Nemzeti Bank versenyképességgel foglalkozó tanulmánya külön kiemeli, hogy a gazdaság fenntartható növekedéséhez szükség van a bankrendszer hitelezésen keresztüli támogató hozzájárulására, ami különösen igaz egy olyan országban, ahol a finanszírozás alapvetôen bankközpontú. Természetesen ehhez mindenképpen szükséges egy hitelezési fordulat, amelyben a kkv-k, a lakossági hitelezések kapják, a növekedési irányt figyelembe véve, a pénzügyi stabilitást. Ez jelenti egyben azt is, hogy technikai újításokat kell bevezetni a banki szolgáltatások területén; ilyenek például az értékesítési csatornák fejlesztése (MNB, 2019).

„...Magyarországnak a gazdasági környezet mutatói közelítették meg átlagban leginkább az uniós átlagot, ez Magyarország legmagasabb szinten teljesített mutatócsoportja a többi mutatóhoz képest. Ez a dimenzió méri a foglalkoztatást a tudásintenzív tevékenységek területén, a közepes és high-tech termékek exportjának hozzájárulását a külkereskedelmi mérleghez, a tudásintenzív szolgáltatások exportját, valamint az új innovációk értékesítését, a licenc és szabadalmi bevételek GDP-hez mért arányát, melyek tekintetében Magyarország teljesítménye a többi területhez mérten magas” (ÁSZ, 2017).

A Magyar Nemzeti Bank a versenyképességi programjának meghirdetése során külön kiemelte, hogy a kutatás-fejlesztés és az innovációs kapacitások alapvetôen meghatározzák a gazdaság megújulási képességét. Az Európai Bizottság European Innovation Scoreboard rendszerében Magyarország továbbra is a mérsékelten innováló országok csoportjába tartozik. A Bizottság pontrendszerén nagyságrendileg 35 százalékos elmaradásban vagyunk az uniós átlagtól, és kevesebb mint a felét éri el hazánk innovációs teljesítménye az európai élvonalat jelentő Svédországénak, de nem szabad elfelejteni, hogy a svédek ezen a területen kiemelt kategóriába tartoznak. Mindemellett a nemzetközi eredmények arra figyelmeztetnek, hogy a gazdasági felzárkózáshoz e tekintetben is csökkenteni kell lemaradásunkat a fejlett államokhoz képest. Ehhez elsôsorban a vállalati $\mathrm{K}+\mathrm{F}-k i a d a ́ s o k a t ~ k e l l ~ e m e l n i$, amelyek mindössze a GDP 0,9 százalékára rúgnak, szemben az 1,3 százalékos uniós átlaggal. A különbség mögött részben a magyar gazdaság duális szerkezete húzódhat meg (Eurostat CIS felmérés, 2015) (MNB, 2019).

\section{AZ OKTATÁSI RENDSZER HELYZETE}

A bolognai rendszer tartalmi sarokköve volt a minőségi oktatás, a gyakorlatorientált képzés, az élethosszig való tanulás elemeinek bevezetése. Nyugaton az évszázadok alatt letisztult felsôoktatási célok és alapelvek értelemszerúen semmi újat nem jelentettek, hiszen az intézményesített felsőoktatási rendszerük sok olyan elemet magában hordozott, melyek segítették a megnevezett paraméterek kialakítását, illetve múködtetésükhöz már rég megtalálta a korszerú oktatási módszertant. Magyarországon a bolognai átalakítási folyamat még közel sem ért véget, hiszen a tapasztalatokat a gyakorlat hozza meg, éppen ezért kiemelt fontosságú volt az érintett szakok áttekintése, az ismeretkörökből származtatható kompetenciák megnevezése. Nemzetközi viszonylatban már több mint tíz éve foglalkoznak ezzel a kérdéskörrel, amely a magyar felsôoktatásban múködố szakok esetében most érkezett el. Ez a többszintú átalakítás, pontosabban kialakítás a jövóben kiemelt jelentôséggel bírhat a tudomány, az oktatás és a gyakorlat 
hármas egységének dinamikus és induktív kapcsolatára. A kialakított kompetenciakörök vertikális és horizontális kapcsolatrendszere, valamint a közöttük lévố összefüggések nagymértékben hozzájárulnak ahhoz, hogy a felhasználok (munkaerôpiac) sokkal jobban átlássák azt a kimeneti tudást, amivel egy végzett hallgatónak rendelkeznie kell a közgazdaságtan szerteágazó rendszerében. Ennek a megvalósítására törekedett a Magyar Rektori Konferencia Gazdaságtudományi Bizottsága is. Véleményem szerint a rendeletben megjelent új képzési követelményrendszer komoly és hatékony reformot is magával hoz az oktatásban, valamint nagymértékben segíti a fokozatváltás programját. A jövơben ki kell emeli az oktatási, képzési reformok szerepét, ugyanakkor figyelmet kell fordítanunk a globalizált világgazdaság és gazdálkodásszervezés kihívásait ellensúlyozó gazdaságtudományi újszerúségek tudományterületi kapcsolatrendszerére, amely a nyugat-európai, amerikai gyakorlatban nem ismeretlen, de hazánkban újszerú szemléletet és gondolkodást jelent. A gazdaságtudományi szakok komoly igényt elégítenek ki, nemcsak a vállalati szférát megcélozva, hanem intézményi szinten is a legnépszerúbbek közé tartoznak a magyar felsôoktatásban. Az alapszakos hallgatók száma hozzávetôleg 40-45000, mesterszakon pedig 8-9000 hallgató folytatja tanulmányait. A nappali képzésre felvettek száma kisebb mértékben csökkent, de a visszaesés szinte mindenhol tapasztalható, és a negatív demográfiai trend sajnos újabb csökkenést hozhat.

A fent leírtakból következóen, a képzés és az alkalmazás dimenzióit egyre nagyobb mértékben össze kell hangolni, azaz interaktívvá kell tenni. Ez óriási feladat, amely a tudásátadás módszertanát is érinti, miközben a globalizáció is jelentôs hatást gyakorol a tradicionális oktatási gyakorlatokra, rendszerekre. Csak az a lehetôségünk maradt, hogy ezeket fejlesztve hatékony és interaktív tudásmenedzsmentet építsünk fel, mert ez lesz a versenyképesség alapja, azaz a tudásátadás hatékonysága és időbeli gyorsasága. A kompetenciákat csak úgy lehet elsajátítani, ha megteremtjük hozzá azt az alapot - gyakorlati vagy akár duális hátteret, megfelelô módszertannal -, amelynek segítségével a hallgatók ezek birtokába juthatnak. Vagyis a jelenlegi szakok keretében múködó oktatási programjainkhoz gyakorlatban megvalósítható interaktív képzési programokat kell kidolgozni, ezeket intézményi szinten fejleszteni, akár külsố kihelyezett gyakorlati tanszékek létrehozásával is (Lentner et al., 2015). Ez hozhatja magával azt a szinergiát, amely segítségével az előbb említett háttér megvalósítható. Erre már ma is találunk példákat, amikor egy egyetem kutatóintézettel vagy vállalattal létesít ilyen jellegú kapcsolatot, az újdonság erejével hathat az is, amikor ez a folyamat kétirányú kapcsolattá válik. Ilyen az MNB és a Corvinus Egyetem makrogazdasági pénzügyekkel foglalkozó tanszéke. Ezeknek az együttmúködéseknek a segítségével folyamatossá, igényszerúvé és erôteljesebbé válhat képzésünk gyakorlatorientáltsága. Megjegyzendô, hogy számtalan külföldi példát ismerünk arra, hogy az országok nemzeti bankja támogatja az adott ország oktatási rendszerét, és részt vesz a képzésekben. Ilyen például a Bank of England együttmúködésének kialakítása a Warwick Business Schoollal. A gazdasági képzések, különös tekintettel a pénzügyi képzéssel foglalkozó szakok stratégiáinak kidolgozásánál jól hasznosíthatók azok a kutatási tapasztalatok, eredmények, melyek megmutatják a szükséges fejlesztési igényeket a gazdaságban. Érdemes arra a tényre is felhívni a figyelmet, hogy azokban az országokban, melyek hatékony pénzügyi képzést szeretnének megvalósítani, illetve 


\section{Zéman Zoltán: A gazdaságtudomány magyarországi helyzete és kapcsolódási pontjai...}

országos szinten kívánják értékelni annak hatásait, ez a kérdés fontos prioritást kap társadalmi és gazdasági szinten egyaránt. A gazdaság irányítóinak módjukban áll meghatározni az adott ország, gazdaság fejlődésének, emellett oktatási kultúrájának potenciális szükségleteit, és feltérképezni mindazokat a hiányosságokat, amelyeket azonosítva gazdaságfejlesztési döntéseket hozhatnak. Ezért a pénzügyi képzés stratégiájának óriási szerepe van az egész oktatási rendszerre nézve (Bárczi-Zéman, 2015).

Mindezek kidolgozásában sokszor nagy léptékú előrehaladások történnek ugyan, de a módszertani kérdésekról sokszor elfeledkeznek, vagy egyáltalán nem foglalkoznak velük. Véleményem szerint minél nehezebb egy ismeretanyag, annál inkább oda kell figyelni a tudásátadás vagy a tudás megszerzésének folyamatára, azaz nem szabad megfeledkezni a módszertani háttérrôl az amúgy is nehéz területekkel kapcsolatban. Megjegyzendô, hogy minél gyorsabban fejlődött egy társadalom, annál nagyobb igény jelentkezett arra vonatkozóan, hogy a gazdasági-pénzügyi viselkedésben rejlő mikro- és makrogazdasági kockázatokat mérsékeljék. Természetesen, a kutatások esetében is csak akkor lehetünk előremutatók, ha a gazdaságtudomány területi megközelítéséből olyan alkalmazható eredmények születnek, amelyek előrébb viszik a problémamegoldásokat a gyakorlati életben is. Így a doktorképzésben is létezik olyan nemzetközileg már elfogadott program - itt kiemelkedô példa az MNB kialakításában szervezendô, egy kiemelt külföldi egyetem akkreditált programjával együttesen szervezôdó képzés -, amely a traszdiszciplinaritást hangsúlyozva, teljesen más tudományos szemszögből ad lehetôséget a problémák tudományos összefüggéseinek feltárására. Sokszor bizonytalanságot okoz a társadalomtudományok és a gazdasági tudományok területén az, hogyan lehet oktatási programokban (doktori) összehangolni a multi-, interdiszciplináris és a transzdiszciplináris kérdésköröket. Megjegyzendő azonban az is, hogy a felgyorsult gazdaságban ezek - még egyszer kiemelve a tudásátadás módszertanát, amelynek minden területen, beleértve a „nemzetköziesedést” is, meg kell újulnia - előbb igényként, majd követelményként jelennek meg. Mindezeket figyelembe véve nem attól értékelôdünk fel a nemzetközi palettán, hogy hány külföldi hallgatónk van, hanem milyen nemzetközi igényú programokat tudunk kiajánlani a világpolgároknak. Úgy gondolom, a külföldi vendégoktatók és -professzorok alkalmazása, a doktori programokhoz való kapcsolódásuk mindezt nagymértékben segítheti. Ebben szintén élen jár az MNB oktatási programot támogató törekvése; ilyen például a geopolitikai kurzusok kapcsolódási pontjainak megtalálása, valamint nemzetközi szintú irányultsága. Megjegyzendő, hogy egyetlen akkreditációs követelményt sem sértve, befogadásra került a Doktori Iskolában. Ez azért egyedülálló, mert európai viszonylatban ilyen magas szinten (doktori programhoz) történő illesztése tudomásom szerint még nem történt meg. Ebben a folyamatban ugyan élen jár az Egyesült Államok és Ausztrália, de most már elmondhatjuk, van egy olyan magyar példa is, amely „kiforrhatja” magát. Megjegyzendő, hogy az ilyen jellegú tevékenység, mint amit az MNB vezetése felvállalt, a nyugati országokban (mint mecenatúra) több évszázad alatt fejlődött ki a civil szféra támogatása révén (Lentner et al., 2015). Az egyes intézmények a belülrôl kifelé irányuló totális sovinizmusukkal magukat fosztották meg az együttmúködés komoly elônyeitôl és lehetôségeitől, de a jelenlegi felsôoktatási intézményi átalakításban kénytelenek ezzel élni. A nyugati országok egyetemei nem zárkóznak el egymástól, egymás módszereinek, tananyagainak 
átvételétôl. Ezért van az, hogy például Philip Kotler Marketingmenedzsmentje, a SydsaeterHammond szerzópáros Matematika közgazdászoknak vagy Brealey és Myers Modern vállalati pénzügyek címú könyve az egész nyugati világban forgatott és elfogadott tananyag minden közgazdasági karon (Czakó et al., 2011). A hasonló együttmúködésben szervezôdô ilyen jellegú kutatások (nemzetközi programok elemzése, értékelése) és a doktori programok olyan újszerú és innovatív tudományos eredményeket vetíthetnek előre, melyek makroés mikroszinten komoly információkat adhatnak a tudományterületekhez.

A szakmai fórumokon sokszor elhangzott, hogy a jövóben kiemelt jelentóséggel bír a tudomány (sciences), az oktatás (education) és a gyakorlat (best practice) hármas egységének dinamikus és induktív kapcsolata. Természetesen ez akkor múködik igazán, ha növeljük a közöttük lévô kapcsolati és funkcionális hatékonyságot. Ebben a folyamatban kiemelkedôen fontossá válik a tudásátadás módszere, annak hatékonysága. Ez nem azt jelenti, hogy nincs időnk oktatni vagy tanítani, hanem azt, hogy gyorsan kell elsajátítanunk a számunkra legfontosabb ismereteket, és mindezt minóségben, versenyképes tudással. Erre irányul a folyamatos kompetenciafejlesztés is, mely továbbra is támaszkodhat a kutatások által megalapozott tudásátadásra. Ugyanakkor új elemként jelenik meg a tudásmenedzsment módszerének didaktikus és folyamatos fejlesztése - ahogy azt az igazi nagyok múvelik, pl. Oxford, Harvard, a skandináv országok -, ehhez járulhatnak a kutatások hatékony tudástranszferek múködtetésével.

Mit is kell értenünk a tudásmenedzselésen? A tudásalapú folyamat menedzselése kétirányú feladatot határoz meg:

- egyfelól a külsố szereplók interaktivitásának fokozására irányul (pl. a munkaerôpiacot kiszolgáló, szinergikus kompetenciafejlesztés), ebben benne van a gyakorlatorientáltság és az élethosszig tartó ismeretkör-bôvítés, azaz tanulás is;

- másrészt az adott szakok és tudományos programok belsố múködési mechanizmusához - természetesen nem figyelmen kívül hagyva a tudományos igényességet - való illesztést jelenti, ami így magában foglalja az innovatív gondolkodást az oktatás területén. Az elóbb említett egységek - tudomány, oktatás, gyakorlat, módszertan, innovatív tudománypolitikai gondolkodás - ilyen jellegú szemlélete komoly elôrelépést jelenthet a minôségi felsôoktatásban. Tehát szakítanunk kell a „hagyományos” oktatási formákkal.

Következésképpen azt is mondhatnánk, hogy a jövó tudásfejlesztésének egyik mozgatórugója ezen egységek összhangja lesz, ami természetesen meghatározóan hat majd a felsôoktatás minőségére is. A nyugati társintézményeknél, ahol tanári végzettséggel oktatnak, tanévenként legalább egy országos oktatásmódszertani, tanulásmódszertani konferenciát rendeznek az oktatóknak. Mindezekből adódóan nem véletlen, hogy a nyugati felsôoktatás Amerikától Ausztriáig ilyen szempontból is teljesen egységesnek túnik. Mindenütt érvényesül a minôségi oktatás, a gyakorlatorientált képzés, az élethosszig tartó tanulás alapelve, mindenhol teret nyertek olyan korszerú oktatásmódszertani megoldások, mint az informatikai támogatás, a kooperativitás, a tanár-diák kapcsolat, a játékosítás, interaktivitás és számos egyéb korszerú módszer. Tulajdonképpen a felsôoktatás minôségét a következô öt alapvetố komponens szabja meg: 1. az oktatók felkészültsége; 2. a hallgatók tudásának minôsége; 3. az oktatási rendszer mint intézményrendszer múködésének hatékonysága; 4. a könyvek, tankönyvek és digitális tananyagok korszerúsé- 


\section{Zéman Zoltán: A gazdaságtudomány magyarországi helyzete és kapcsolódási pontjai...}

ge; 5 . az alkalmazott módszertan - amely meghatározza a tudásátadás és tudásmegszerzés gyorsasági fokát - illeszthetôsége a gazdasági és társadalmi szintekhez.

A magyar felsôoktatást vizsgálva elmondhatjuk, hogy az elsố három komponens fejlesztése is óriási feladat - bár intézményenként elég eltéró viszonyokat találunk -, ami természetesen nem jó, de még elfogadható. Viszont a tananyag és az alkalmazott módszertan már nem egységes, következésképpen ez egyaránt mennyiségi és minôségi probléma is (Lentner, 2017). Ismételten fel kell hívnom a figyelmet arra, hogy a Magyar Nemzeti Bank mecenatúrájával történelmi fordulatot fog elóidézni nemcsak a közgazdasági felsôoktatásban, hanem az egész magyar felsôoktatásban. Ha bebizonyosodik, hogy igenis van a korszerú tananyag elóállítására olyan modell, illetve az alkalmazhatósághoz társítható intézményi struktúra, ami önfinanszírozó, korszerú és folyamatosan megújuló a közgazdasági felsốoktatásban, akkor bizonyára a többi tudományág területén múködô felsôfokú intézmények is átveszik ezt a gyakorlatot. Ugyanakkor senki sem gondolhatja komolyan azt a kritikát, mely szerint a MNB ezzel a mecenatúrájával sérti az intézményi autonómiát és tanszabadságot. A tudománynak és végsố soron a gyakorlatnak, tehát a való életnek meg kell vitatnia az új gondolatokat, új megközelítéseket, újszerú megoldásokat. A magyar innovációk mindig fontos szerepet játszottak és játszanak a világ fejlôdésében, még akkor is, ha többnyire elszigetelt, egyéni, zseniális szellemi erôfeszítések eredményeirôl beszélhetünk. A közeljövôben azonban a zsenik felfedezése mellett tömegek (ha nem is zseniális) szellemi erôfeszítéseit, tömeges tudást igényelnek az innovatív fejlesztések széles körú megismerése, alkalmazása, illetve használata. A várható radikális technikai, technológiai fordulathoz megalapozott, széles körú, az egész társadalmat átfogó tudásra van szükség. Az okoseszközök és innovatív megoldások csak okos, felkészült társadalmakban múködnek és múködtethetôk. Aki kimarad a felkészülésból, az lemarad a fejlôdésben. A közeljövố meghatározó feladata lesz a minôségi tudás elóállítása és megfelelố menedzselése, melynek színterei nyilvánvalóan csak az egyetemek lehetnek. Ez esetben a konkrét pénzügyi ismeretek bóvítése, az állam vagy a pénzintézetek által támogatott oktatási formák, ismeretterjesztô anyagok lehetséges eszközt jelenthetnek a helyzet javítására, amit az MNB kötelességtudóan bevállalt, illetve igyekszik teljesíteni. A magyar gazdaságpolitikai modellben nemcsak a fiskális és a monetáris politika összehangolásában, hanem az elóbb vázolt oktatási kérdésekben is igyekszik minél nagyobb támogatást nyújtani a jegybank (Lentner, 2016, 2017). Az oktatási rendszer egyik legnagyobb feladata, hogy a munkaerôpiac olyan jövóbeli állapotára készítse fel a fiatalokat, amelyek elôrejelzése a gyorsuló technológiai fejlődés miatt egyre nehezebb. A felsôoktatási rangsorokban való elôrelépés csak tudatos fejlesztéssel és célzott intézkedésekkel (fốként az oktatói kar megerôsítésével) érhetô el (MNB, 2019).

Összességében tehát elmondható, hogy a pénzügyi ismeretek szintje befolyásolja a gazdaság stabilitását, ezért számos fejlett ország jegybankja vállal aktív szerepet a lakosság pénzügyi ismereteinek növelésében, a pénzügyi kultúra fejlesztésében, annak terjesztésében (Béres, 2013). Természetesen bôven van még feladat és teendô, de mindenképpen nagyot léptünk elôre. Megjegyzendố azonban az, hogy mindig lesznek újabb feladatok a környezet és a világ változásának függvényében, és ezeket a változásokat kell jól menedzselnünk, hogy a legjobbat hozzuk ki a gazdaság és magunk fejlődése érdekében. 
Polgári Szemle $\cdot 15$. évfolyam 1-3. szám

\section{FELHASZNÁLT IRODALOM}

Anderson, John - Gonzalez, Adrian (2012): Does Doing Business Matter for Foreign Direct Investment? The World Bank.

ÁSZ (2017): A magyar kutatás-fejlesztés és innovációs tevékenység eredményessége. Állami Számvevôszék, Budapest, május.

Bárczi Judit - Zéman Zoltán (2015): A pénzügyi kultúra és annak anomáliái. Polgári Szemle, 11. évf., 1-3. sz.

Béres Dániel (2013): A pénzügyi kultúra - mi is ez valójában? Pénzügyi Szemle Online, www.penzugyiszemle. $\mathrm{hu} /$ vitaforum/a-penzugyi-kultura-mi-is-ez-valojaban.

Bijsterbosch, Martin - Marcin Kolasa (2009): FDI and Productivity Convergence in Central and Eastern Europe. An Industry-Level Investigation. ECB Working Paper Series, 992.

Borzán Anita - Lentner Csaba - Szigeti Cecília (2011): A pénzügyi vállalkozások felelôsségvállalásának új dimenziói. Economica, Vol. 4, No. 11, 22-30.

Czakó Ágnes - Husz Ildikó - Szántó Zoltán (2011): Meddig nyújtózkodjunk? A magyar háztartások és vállalkozások pénzügyi kultúrájának változása a válság idôszakában. BCE Innovációs Központ, Budapest.

EC (2012): The 2012 Ageing Report: Economic and Budgetary Projections for the 27 EU Member States (20102060). European Economy 2/2012, European Commission.

Egan, Michelle (2003): Constructing a European Market: Standards, Regulation, and Governance. Oxford Scholarship Online, https://doi.org/10.1093/0199244057.001.0001.

EIB (2013): Banking in Central and Eastern Europe and Turkey. Challenges and Opportunities. European Investment Bank.

ENSTOE (2012): Statistical Yearbook 2011. European Network of Transmission System Operators for Electricity, Brussels.

Farrell, Diana et al. (2006): Sweden's Economic Performance: Recent Developments, Current Priorities. May, McKinsey Global Institute.

Hittig, Gusztáv - Gál, Zsolt - Zéman, Zoltán - Bárczi, Judit (2018): A New Dawn: Possibility of Reigniting Growth With $\mathrm{R}+\mathrm{D}+\mathrm{I}$ Management in 16+1 Cooperation (Case Study from Hungary's Point of View). Modern Science, No. 4, 34-57.

International Energy Agency (2007): Tackling Investment Challenges in Power Generation in IEA Countries. OECD, https://doi.org/10.1787/9789264030084-en.

Lentner, Csaba - Szigeti, Cecília - Borzán, Anita (2011): New Dimensions of Banks Social Responsibility. In: Szente, Viktória et al. (eds.): Sustainable Economics, Community Strategies. Abstracts of the 3rd International Conference of Economic Sciences. Kaposvár University, Kaposvár, 29-48.

Lentner Csaba - Szegedi Krisztina - Tatay Tibor (2015): Társadalmi felelôsségvállalás a bankszektorban. Pénzügyi Szemle, 60. évf., 1. sz., 96-104.

Lentner Csaba (2016): A gazdasági válság hatása a globális, uniós és hazai szabályozási környezetre. In: Auer, Ádám - Papp, Tekla (szerk.): A gazdasági világválság hatása egyes jogintézményekre Magyarország és az Európai Unióban. Interdiszciplináris és jogösszehasonlító elemzés. Budapest, NKE, 45-84.

Lentner, Csaba (2017): Scientific Taxonomy of Hungarian Public Finances After 2010. Polgári Szemle / Civic Review, Vol. 13, Special Issue, 21-38. https://doi.org/10.24307/psz.2017.0303.

Manyika, James (2012): Manufacturing the Future: The Next Era of Global Growth and Innovation. McKinsey Global Institute.

MNB (2019): Versenyképességi program 330 lépésben. Magyar Nemzeti Bank, https://www.mnb.hu/letoltes/ versenykepessegi-program.pdf.

Teicholz, Paul (2013): Labour-Productivity Declines in the Construction Industry: Causes and Remedies. AECbytes, March 14.

Zéman, Zoltán - Gábor, Ágnes - Bárczi, Judit - Gál, Zsolt (2018): The Role of Controlling in Sustainable Development and Competitiveness. In: Zéman, Zoltán et al. (eds.): Theory and Practice of Social, Economic and Technological Changes. Nemoros, Prague, 8-19. 